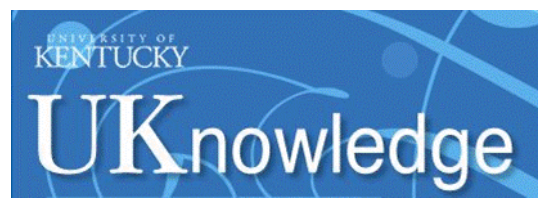

University of Kentucky

UKnowledge

\title{
Population-Based Survey of Complementary and Alternative Medicine Usage, Patient Satisfaction, and Physician Involvement
}

\author{
Robert Oldendick \\ University of South Carolina, roldendi@mailbox.sc.edu \\ Ann L. Coker \\ University of South Carolina, ann.coker@uky.edu \\ Darryl Wieland \\ University of South Carolina, dwieland@mailbox.sc.edu \\ James I. Raymond \\ University of South Carolina \\ Janice C. Probst \\ University of South Carolina, jprobst@mailbox.sc.edu
}

See next page for additional authors

Follow this and additional works at: https://uknowledge.uky.edu/crvaw_facpub

Part of the Alternative and Complementary Medicine Commons, and the Public Health Commons Right click to open a feedback form in a new tab to let us know how this document benefits you.

\section{Repository Citation}

Oldendick, Robert; Coker, Ann L.; Wieland, Darryl; Raymond, James I.; Probst, Janice C.; Schell, Bruce J.; and Stopskopf, Carleen H., "Population-Based Survey of Complementary and Alternative Medicine Usage, Patient Satisfaction, and Physician Involvement" (2000). CRVAW Faculty Journal Articles. 135.

https://uknowledge.uky.edu/crvaw_facpub/135

This Article is brought to you for free and open access by the Center for Research on Violence Against Women at UKnowledge. It has been accepted for inclusion in CRVAW Faculty Journal Articles by an authorized administrator of UKnowledge. For more information, please contact UKnowledge@lsv.uky.edu. 


\section{Population-Based Survey of Complementary and Alternative Medicine Usage, Patient Satisfaction, and Physician Involvement}

\section{Notes/Citation Information}

Published in Southern Medical Journal, v. 93, no. 4, p. 375-381.

Dr. Ann Coker had not been a faculty member of the University of Kentucky at the time of publication.

Authors

Robert Oldendick, Ann L. Coker, Darryl Wieland, James I. Raymond, Janice C. Probst, Bruce J. Schell, and Carleen H. Stopskopf 


\section{Population-Based Survey of Complementary and Alternative Medicine Usage, Patient Satisfaction, and Physician Involvement}

ROBERT OLDENDICK, PhD, ANN L. COKER, PhD, DARRYL WIELAND, PhD, JAMES I. RAYMOND, MD, JANICE C. PROBST, PhD, BRUCE J. SCHELL, PhD, and CARLEEN H. STOSKOPF, ScD, for the South Carolina Complementary Medicine Program Baseline Research Team,* Columbia, SC

\section{ABSTRACT}

Background. With an increasing proportion of Americans using complementary or alternative medicine (CAM), physicians need to know which patients are using CAM to effectively manage care.

Methods. In this cross-sectional study, telephone interviews were conducted with 1,584 South Carolina adults (ages 18 and older); $66 \%$ responded to the survey of demographics, general health, frequency of CAM use, perceived CAM effectiveness, and physician knowledge of CAM use.

Results. A total of $44 \%$ had used a CAM during the past year. Increasing age and higher education were significantly associated with CAM use. More than $60 \%$ perceived CAM therapy as very effective, and $89 \%$ said they would recommend CAM to others. Physicians were unaware of CAM use in $57 \%$ of their patients using CAM.

Conclusion. Complementary or alternative medicine use in this rural Southern state is similar to national usage. Users view CAM as effective. Physicians are frequently unaware of patients' CAM use. More research is needed to establish CAM effectiveness and how CAM affects medical care, training, and public health.

MORE THAN $40 \%$ of Americans are using complementary or alternative medicine (CAM) to treat a range of health conditions or to stay healthy, ${ }^{1 \cdot 3}$ and this usage increased during the 1990 s. $^{\prime}$ Eisenberg et $\mathrm{al}^{1}$ reported that $42.1 \%$ of American adults had used at least one CAM

\footnotetext{
*Team members include Ann L. Coker, PhD, and Carleen H. Stoskopf, ScD, co-chairs; and Joyce B. Brown, MSN, RN; Suzanne: Catalano, MBA; Noel O'R. Morton, MPA, MA; Robert Oldendick, PhD; Evelyn J. Phillips, LMSW; Janice C. Probst, PhD; Bruce J. Schell, PhD; and Linda Sharkey, MS.

From the Survey Research Laboratory, Institute of Public Affairs; the Department of Epidemiology and Biostatistics, School of Public Health; the Division of Geriatrics and the Department of Family and Preventive Medicine, School of Medicine; and the Department of Health Administration, School of Public Health, University of South Carolina, Columbia. (Dr. Raymond is with the Department of Medical Education and Research, Palmetto Health Alliance.)

Supported by Palmetto Health Alliance of Columbia, SC to the South Carolina Complementary Medicine Program. The South Carolina Complementary Medicine Program is a multidisciplinary partnership initiative of the University of South Carolina Institute of Public Affairs and Palmetto Health Alliance, and is housed in the Center for Health Services and Policy Research in Columbia.

Reprint requests to Robert Oldendick, $\mathrm{PhD}$, University of: South Carolina, Institute of Public Affairs, Survey Research Laboratory, Columbia, SC 29208.
}

therapy within the past year (1997), and a commercial study by Landmark Healthcare Inc $^{2}$ reported the same figure (42\% in 1997). Nearly 1 in 10 Americans surveyed as part of the 1994 Robert Wood Johnson Foundation's National Access to Care Study ${ }^{4}$ saw a professional for one of the following four therapies: chiropractic, relaxation techniques, therapeutic massage, or acupuncture. The annual outof-pocket expenditures in 1997 relating to alternative therapies are estimated at more than $\$ 27$ billion.' Comparable studies of national populations of Canada ${ }^{5}$ and Australia ${ }^{6}$ indicate the trend is not limited to the United States. Further showing the rising prevalence of CAM are such indicators as the increasing demand for and provision of insurance coverage for complementary and alternative care ${ }^{7,8}$ and the large percentage of US medical schools (64\%) currently offering courses that address CAM. ${ }^{9}$

Physicians and patients need to know more about the effectiveness of CAM for specific medical conditions and whether such thera- 
pies interact adversely with prescribed treatments. To manage their patients' care effectively, physicians also need to know which of their patients are using specific CAM therapies.

Although several recent studies have examined CAM use at the national level, ${ }^{14,10}$ there have been few state-based investigations. ${ }^{11}$ This study examines CAM use in a state with a large black minority, rural, and low-income population. We report on the lifetime use and past 12 months' frequency of CAM use for 23 therapies that are generally considered to be "complementary" or "alternative." These findings are based on a telephone survey of 1,584 South Carolina adults. We also present demographic correlates of CAM use, user satisfaction with CAM therapies, and involvement of physicians in the use of CAM.

\section{METHODS}

\section{Definition}

Alternative, complementary, or unconventional health care interventions are difficult to define. ${ }^{10,12-15}$ The classification as "alternative" is defined in relation to a "mainstream." Neither alternative nor mainstream is static in terms of what it encompasses. We adopted a version of the operational definition used by Eisenberg et $\mathrm{al}^{5}$ and the National Center for Complementary and Alternative Medicine of the National Institutes of Health ${ }^{15}$ : medical interventions not taught widely at US medical schools nor generally available at US hospitals. This definition permits the inclusion of a wide range of therapies and, given our initial focus on the use of "alternative" therapies among the public, enables us to identify those treatments that the general population considers to be outside the traditional mainstream.

\section{Survey}

For this cross-sectional study, telephone interviews were conducted with 1,584 South Carolina adults (aged 18 and older) selected by random-digit dial techniques. The response rate for this survey was $66.2 \%$. The questionnaire included items on respondents' general health, specific health conditions, use of alternative therapies (lifetime and in the past 12 months), the perceived effectiveness of the CAM therapy, whether a doctor or other health care professional had recommended the CAM therapy, and, if not, whether they had informed their doctor of the therapy use. All CAM users were also asked (1) whether they would recommend the therapy to a friend or family member, and (2) whether they had ever had a bad experience with the therapy. The term "complementary or alternative medicine" was not used in the questionnaire; rather, respondents were asked about their experience with specific therapies as well as an open-ended item on "any other" types of treatment.

\section{Statistical Analysis}

The data were weighted so that the characteristics of the sample reflect those of the South Carolina adult population on the basis of age, race, and sex. All analyses were conducted using SPSS. ${ }^{16}$ We calculated $95 \%$ confidence intervals for the frequency of CAM use by type. ${ }^{17}$ Statistical differences in CAM use by demographic attributes were identified using chi-square tests at an $\alpha$ level of .05. ${ }^{18}$

TABLE 1. Frequency of Complementary or Alternative Medicine (CAM) Use Among 1,584 Residents Responding to the Random-Digit Dial Survey

\begin{tabular}{|c|c|c|c|c|c|c|}
\hline \multirow[b]{2}{*}{ CAM Therapy } & \multicolumn{3}{|c|}{ Any CAM Use (During Lifetime) } & \multicolumn{3}{|c|}{ CAM Use in the Past 12 Months } \\
\hline & No. & $\%$ & (95\% CI for \%) & No. & $\%$ & $(95 \%$ CI for \%) \\
\hline $\begin{array}{l}\text { Any use of complementary } \\
\text { or alternative medicine }\end{array}$ & 801 & $51.7 \%$ & $(49.2-54.2 \%)$ & 677 & $43.7 \%$ & $(41.2-46.2 \%)$ \\
\hline $\begin{array}{l}\text { Personal therapies (including home } \\
\text { remedies, herbal medicine, } \\
\text { homeopathy, or vitamin therapy) }\end{array}$ & 427 & $27.5 \%$ & $(25.3-29.9 \%)$ & 388 & $25.0 \%$ & $(22.9-27.3 \%)$ \\
\hline $\begin{array}{l}\text { Relaxation techniques (including } \\
\text { massage therapy, imagery, } \\
\text { or visualization) }\end{array}$ & 399 & $25.7 \%$ & $(23.6-28.0 \%)$ & 348 & $22.5 \%$ & $(20.4-24.6 \%)$ \\
\hline Chiropractors & 317 & $20.5 \%$ & (18.5-22.6\%) & 135 & $8.7 \%$ & $(7.4-10.2 \%)$ \\
\hline $\begin{array}{l}\text { Healing (including healers, spiritual } \\
\text { healing, Native American healers, } \\
\text { or energy healing) }\end{array}$ & 73 & $4.6 \%$ & $(3.7-5.9 \%)$ & 66 & $4.2 \%$ & $(3.3-5.4 \%)$ \\
\hline Commercial weight loss programs & 69 & $4.5 \%$ & $(3.5-5.6 \%)$ & 38 & $2.5 \%$ & $(1.7-3.4 \%)$ \\
\hline Life-style diets & 67 & $4.3 \%$ & $(3.4-5.5 \%)$ & 60 & $3.9 \%$ & $(3.0-5.0 \%)$ \\
\hline Self-help groups & 41 & $2.6 \%$ & $(1.9-3.6 \%)$ & 33 & $2.1 \%$ & $(1.5-3.0 \%)$ \\
\hline Hypnosis or biofeedback & 30 & $1.9 \%$ & $(1.3-2.8 \%)$ & 10 & $0.6 \%$ & $(0.3-1.2 \%)$ \\
\hline
\end{tabular}


TABLE 2. Reasons Respondents Gave for Using Specific CAM Therapies

\begin{tabular}{|c|c|c|c|c|c|c|c|c|c|}
\hline \multirow{3}{*}{$\begin{array}{c}\text { Type of } \\
\text { CAM } \\
\text { Therapy }\end{array}$} & \multirow{3}{*}{$\begin{array}{c}\text { No. } \\
\text { CAM } \\
\text { Users }\end{array}$} & \multicolumn{7}{|c|}{ Why CAM Therapy Was Used } & \\
\hline & & To & \multicolumn{7}{|c|}{ To Treat a Specific Health Problem } \\
\hline & & $\begin{array}{c}\text { Stay } \\
\text { Healthy }\end{array}$ & $\begin{array}{c}\text { Musculoskeletal } \\
\text { or Neurologic }\end{array}$ & Psychosocial & $\begin{array}{c}\text { Cardiovascular/ } \\
\text { Hormonal/Metabolic }\end{array}$ & $\begin{array}{l}O B-G Y N / \\
\text { Urogenital }\end{array}$ & Gastrointestinal & $\begin{array}{c}\text { Allergy/ } \\
\text { Respiratory }\end{array}$ & Other \\
\hline Personal therapies & 622 & $48.4 \%$ & $10.9 \%$ & $1.4 \%$ & $3.5 \%$ & $5.6 \%$ & $2.9 \%$ & $17.7 \%$ & $9.6 \%$ \\
\hline Relaxation & 478 & $55.9 \%$ & $22.0 \%$ & $13.0 \%$ & $1.3 \%$ & $1.0 \%$ & $0.6 \%$ & $1.0 \%$ & $5.2 \%$ \\
\hline Chiropractors & 332 & $12.3 \%$ & $82.6 \%$ & $1.2 \%$ & $0.3 \%$ & $0.3 \%$ & $1.2 \%$ & $1.8 \%$ & $0.3 \%$ \\
\hline Healing & 87 & $59.8 \%$ & $8.0 \%$ & $5.7 \%$ & $3.4 \%$ & $3.4 \%$ & $3.4 \%$ & $2.3 \%$ & $14.0 \%$ \\
\hline $\begin{array}{l}\text { Commercial weight } \\
\text { loss programs }\end{array}$ & 82 & $75.6 \%$ & $1.2 \%$ & $1.2 \%$ & $20.8 \%$ & $0.0 \%$ & $0.0 \%$ & $0.0 \%$ & $1.2 \%$ \\
\hline Life-style diet & 67 & $85.1 \%$ & $3.0 \%$ & $0.0 \%$ & $10.4 \%$ & $0.0 \%$ & $1.5 \%$ & $0.0 \%$ & $0.0 \%$ \\
\hline Self-help & 44 & $40.9 \%$ & $9.1 \%$ & $2.3 \%$ & $2.3 \%$ & $0.0 \%$ & $0.0 \%$ & $2.3 \%$ & $34.1 \%$ \\
\hline $\begin{array}{l}\text { Hypnosis or } \\
\text { biofeedback }\end{array}$ & 41 & $41.5 \%$ & $4.9 \%$ & $12.2 \%$ & $12.2 \%$ & $0.0 \%$ & $4.9 \%$ & $0.0 \%$ & $14.6 \%$ \\
\hline $\begin{array}{l}\text { All other CAM } \\
\text { therapies }\end{array}$ & 78 & $23.1 \%$ & $26.9 \%$ & $1.3 \%$ & $9.0 \%$ & $10.3 \%$ & $13.9 \%$ & $8.9 \%$ & $6.3 \%$ \\
\hline
\end{tabular}

\section{RESULTS}

\section{Use of Complementary and Alternative Medicine}

Table 1 provides the number and proportion of respondents who reported lifetime and recent CAM use by specific therapy groupings. Complementary or alternative medicine therapies were grouped according to similarity of the therapies and presented by prevalence of use. In this population, almost $52 \%$ reported use of at least one CAM therapy in their lifetime, and $44 \%$ reported use of at least one of the listed CAM therapies during the past 12 months. The most commonly reported CAM therapy grouping, classified as personal therapies, included home remedies, herbal therapy, vitamins, or homeopathy $(27.5 \%$ reported use during their lifetime). This grouping was followed closely by relaxation therapies $(25.7 \%$ reported lifetime use of massage therapy, imagery, or visualization). One in every 5 surveyed had used a chiropractor in their lifetime, while 1 in 12 had used a chiropractor in the past 12 months. A much smaller proportion (4.6\% lifetime use) reported using healing therapies (including healers, spiritual healing, Native American healers, or energy healing), commercial weight loss programs $(4.5 \%)$ or life-style diets $(4.3 \%)$, self-help or support groups $(2.6 \%)$, and hypnosis or biofeedback $(1.9 \%)$. Less than $1 \%$ of those interviewed reported any use of other types of CAM therapies (data not shown).

\section{Reasons for CAM Use}

Respondents who reported using a CAM therapy were asked whether they used this treatment primarily to stay healthy or to treat some health problem. Overall, $47 \%$ of reported CAM use was to maintain health rather than as treatment for a specific health condi- tion, though as the data in Table 2 indicate, there was significant variation by type of CAM treatment. A large majority of those who used life-style diets $(85.1 \%)$ and commercial weight loss programs $(75.6 \%)$ did so primarily to stay healthy, and a majority of the use of healing therapies $(59.8 \%)$ and relaxation therapies $(55.9 \%)$ was to maintain health. Slightly less than half of the use of personal therapies was to maintain health, and a relatively high percentage of such use was for treatment of allergies or other respiratory problems (17.7\%). Those using chiropractors were disproportionately using this therapy to treat a specific health condition $(87.7 \%)$, most of which involved a musculoskeletal or neurologic problem. The relatively high percentage of those who used a self-help group to treat "other" health problems represents participants in cancer survivor groups.

\section{Demographics of CAM Use}

Table 3 provides demographic characteristics of those ever using or recently using any CAM therapy. Women were significantly more likely than men to use CAM therapies. White respondents were more likely to report at least one CAM use than were black respondents; however, there were not significant differences in recent CAM use by race. Middle-aged and older respondents were significantly more likely to use a CAM therapy than those younger than 30 . Almost $50 \%$ of those with some college education were recent CAM users, compared with approximately a $40 \%$ CAM use rate among those with a high school education or less. Divorced or separated respondents were significantly more likely to report CAM use than were married, widowed, or single respondents. Living in an urban or rural 
TABLE 3. Demographic Characteristics of Respondents Using Complementary or Alternative Medicine (CAM)

\begin{tabular}{|c|c|c|c|c|c|}
\hline \multirow{2}{*}{$\begin{array}{l}\text { Demographic } \\
\text { Characteristics }\end{array}$} & \multirow{2}{*}{$\begin{array}{l}\text { No. of Respondents } \\
\text { in Demographic Sirata }\end{array}$} & \multicolumn{2}{|c|}{ Any CAM Use } & \multicolumn{2}{|c|}{ CAM Use in the Past 12 Month } \\
\hline & & No. & Weighted \% & No. & Weighted \% \\
\hline All respondents & 1,556 & 801 & $51.7 \%$ & 677 & $43.7 \%$ \\
\hline Sex & & * & & + & \\
\hline Male & 591 & 357 & $49.0 \%$ & 294 & $40.3 \%$ \\
\hline Female & 965 & 435 & $54.8 \%$ & 378 & $47.5 \%$ \\
\hline Race & & + & & & \\
\hline Black & 345 & 178 & $45.9 \%$ & 158 & $40.7 \%$ \\
\hline White & 1,142 & 582 & $54.5 \%$ & 486 & $45.5 \%$ \\
\hline $\begin{array}{l}\text { Other (Asian, Hispanic, } \\
\text { Native American) }\end{array}$ & 21 & $\mathrm{NE}$ & & NE & \\
\hline Not stated & 76 & & & & \\
\hline Age & & $\dagger$ & & + & \\
\hline $18-29$ & 290 & 164 & $40.1 \%$ & 146 & $35.7 \%$ \\
\hline $30-45$ & 470 & 294 & $58.4 \%$ & 261 & $51.0 \%$ \\
\hline $46-64$ & 442 & 206 & $59.4 \%$ & 170 & $48.9 \%$ \\
\hline 65 or older & 312 & 114 & $50.7 \%$ & 85 & $37.8 \%$ \\
\hline Not stated & 70 & & & & \\
\hline Education & & $t$ & & + & \\
\hline Less than high school & 274 & 115 & $48.7 \%$ & 95 & $40.3 \%$ \\
\hline High school diploma & 459 & 217 & $46.6 \%$ & 178 & $38.2 \%$ \\
\hline Some college & 401 & 250 & $59.2 \%$ & 210 & $49.5 \%$ \\
\hline College graduate & 376 & 195 & $54.6 \%$ & 177 & $49.4 \%$ \\
\hline Not stated & 74 & & & & \\
\hline Family income & & & & $*$ & \\
\hline Less than $\$ 15,000$ & 252 & 107 & $52.2 \%$ & 97 & $47.3 \%$ \\
\hline$\$ 15,000-\$ 29,999$ & 319 & 176 & $52.5 \%$ & 151 & $45.1 \%$ \\
\hline$\$ 30,000-\$ 49,999$ & 330 & 173 & $51.2 \%$ & 140 & $41.5 \%$ \\
\hline$\$ 50,000$ and over & 328 & 211 & $60.1 \%$ & 187 & $53.1 \%$ \\
\hline Not stated & 355 & $\mathrm{NE}$ & & $\mathrm{NE}$ & \\
\hline Marital status & & + & & + & \\
\hline Married or living as married & 850 & 469 & $55.2 \%$ & 392 & $46.2 \%$ \\
\hline Widowed & 201 & 107 & $53.2 \%$ & 86 & $42.8 \%$ \\
\hline Divorced or separated & 215 & 146 & $67.9 \%$ & 129 & $60.0 \%$ \\
\hline Never married & 240 & 116 & $48.3 \%$ & 108 & $45.0 \%$ \\
\hline Missing & 78 & & & & \\
\hline \multicolumn{6}{|l|}{ Urban or rural county of residence } \\
\hline Urban counties & 565 & 287 & $51.5 \%$ & 248 & $44.4 \%$ \\
\hline Rural counties & 991 & 506 & $51.8 \%$ & 423 & $43.4 \%$ \\
\hline $\begin{array}{l}* P \text { value }=.01-.05 \text { for chi-square } \\
\dagger P \text { value }<.01 \text { for chi-square test. } \\
\mathrm{NE}=\text { Proportion not estimated. }\end{array}$ & & & & & \\
\hline
\end{tabular}

area was not significantly associated with CAM use.

Using these background characteristics as independent variables in logistic regression models of lifetime and past 12 month use of CAM therapies shows age to be the most important predictor of CAM use at some point during a lifetime, while higher education is the best predictor of CAM use during the past 12 months. Race, income, and sex were not significant correlates of CAM use after adjusting for age and education.

\section{Satisfaction With Alternative Therapies}

Table 4 provides the results of respondents' assessment of CAM effectiveness (extremely, very, somewhat, not too, or not at all effective), whether they reported a bad experience with any CAM therapy, and whether they would recommend the treatment to a friend or family member. As the figure for any CAM use indicates, $63.3 \%$ of users perceived their therapy to be very or extremely effective, though there was some variation among types of CAM therapies. Those 68 using commercial weight loss programs were least likely to report this therapy as extremely or very effective $(44.9 \%)$, whereas the 73 respondents using a range of healing therapies were most likely to rate these therapies as effective $(79.3 \%)$. About $10 \%$ of those using commercial weight loss programs and $10 \%$ of those using hypnosis or biofeedback reported a bad experience with these therapies. Those using healing therapies were significantly more likely to perceive this therapy to be effective relative to all other therapies, while those using commercial weight loss programs were significantly less likely to report this therapy as effective. Less than $5 \%$ of CAM users reported a bad experience with the CAM therapy. Those using hypnosis or biofeedback and those using commer- 
TABLE 4. Measures of Satisfaction With Complementary and Alternative Medicine Therapies

\begin{tabular}{|c|c|c|c|c|}
\hline $\begin{array}{l}\text { Type of } \\
\text { CAM } \\
\text { Therapy }\end{array}$ & $\begin{array}{l}\text { No. of } \\
\text { CAM } \\
\text { Users }\end{array}$ & $\begin{array}{l}\text { \% Reporting } \\
\text { CAM as } \\
\text { Extremely or } \\
\text { Very Effective }\end{array}$ & $\begin{array}{l}\text { \% Having "Bad } \\
\text { Experience" With } \\
\text { CAM Therapy }\end{array}$ & $\begin{array}{l}\text { \% Who Would } \\
\text { Recommend CAM } \\
\text { to Friends/Family }\end{array}$ \\
\hline $\begin{array}{l}\text { Personal therapies (including home } \\
\text { remedies, herbal medicine, } \\
\text { homeopathy, or vitamin therapy) }\end{array}$ & 425 & $62.0 \%$ & $4.0 \%$ & $87.8 \%$ \\
\hline $\begin{array}{l}\text { Relaxation techniques (including } \\
\text { massage therapy, imagery, } \\
\text { or visualization) }\end{array}$ & 399 & $64.1 \%$ & $2.4 \%$ & $92.0 \%$ \\
\hline Chiropractors & 314 & $63.1 \%$ & $7.7 \%$ & $86.3 \%$ \\
\hline $\begin{array}{l}\text { Healing (including healers, spiritual, } \\
\text { healing, Native American healers, } \\
\text { or energy healing) }\end{array}$ & 73 & $79.3 \%$ & $3.2 \%$ & $89.2 \%$ \\
\hline Commercial weight loss programs & 68 & $44.9 \%$ & $10.5 \%$ & $69.4 \%$ \\
\hline Life-style diets & 65 & $72.0 \%$ & $7.4 \%$ & $82.3 \%$ \\
\hline Self-help groups & 41 & $73.7 \%$ & $7.5 \%$ & $88.2 \%$ \\
\hline Hypnosis or biofeedback & 29 & $59.8 \%$ & $10.9 \%$ & $80.7 \%$ \\
\hline Any CAM use & 801 & $63.3 \%$ & $4.7 \%$ & $87.7 \%$ \\
\hline
\end{tabular}

cial weight loss programs were most likely to report a bad experience. More than $85 \%$ of CAM users said they would recommend these: therapies to friends or family members. Those using commercial weight loss programs were least likely to recommend this therapy $(69.4 \%)$, while those using relaxation techniques $(92 \%)$ were most likely to recommend the therapy.

\section{Physician Involvement With Alternative Therapies}

Table 5 presents the proportion of CAM users whose physician or other health care professional recommended the CAM therapy. Those whose health care professional did not recommend the CAM therapy were also asked whether they had informed their physician about their CAM use. We combined this information to provide the proportion of CAM use of which doctors were unaware. These data show distinctions in the types of alternative therapies that physicians recommend and, consequently, in the percentage of physicians who are aware of the use of these complementary treatments. Physicians recommended biofeedback for $39.3 \%$ of users of this therapy and for one third of those using life-style diets, selfhelp groups, and relaxation techniques. Physicians were least likely to recommend healing therapies $(7.4 \%)$, and thus physicians were least likely to be informed of their patients' use of healing therapies $(72.9 \%)$. Physicians were most likely to be aware of self-help or support group participation and life-style diets.

Users of CAM therapies received information about these treatments from a number of different sources. While about 1 in 5 users identified a medical doctor as the primary source of their information about CAM therapies, a similar percentage $(20.1 \%$ ) cited a spouse or other relative as their source of information. Smaller percentages mentioned magazines $(16.4 \%)$, a friend or neighbor $(9.2 \%)$, their own experience $(8.8 \%)$, television $(6.0 \%)$, books $(5.3 \%)$, newspapers $(4.2 \%)$, or other health care professionals $(4.1 \%)$.

\section{DISCUSSION}

Our survey in South Carolina, a rural state with a large minority population, found that consumers' use of complementary and alternative therapies is similar to that found in contemporary national studies. ${ }^{1.3}$ The unique characteristics of the state and region do not seem to translate into differences in CAM use, either in terms of overall prevalence or in the use of specific treatments. Recent national surveys by Eisenberg et al $^{\prime}$ and Landmark Healthcare Inc $^{2}$ showed that $42 \%$ of the American adult public had used at least one CAM therapy during the past 12 months (1997). The comparable figure for the state of South Carolina approximately 1 year later is $44 \%$, and use of therapies such as herbal medicine, life-style diets, and vitamin therapy during the past 12 months was virtually identical to that reported by Eisenberg et al.' Personal therapies (such as home remedies and herbal medicine) and relaxation therapies were found to be the most prevalent, and about half of the users of these specific treatments used them to maintain health rather than to treat ailments. Middle-aged health care consumers were most likely to report using CAM at least once during their lifetime, and advanced education was the best predictor of use within the past year. With some differences across 
TABLE 5. Physician Involvement in Their Patients' Use of Complementary or Alternative Medical Therapy

\begin{tabular}{|c|c|c|c|c|}
\hline $\begin{array}{c}\text { Type of } \\
\text { CAM } \\
\text { Therapy } \\
\end{array}$ & $\begin{array}{l}\text { No. of } \\
\text { CAM } \\
\text { Users } \\
\end{array}$ & $\begin{array}{c}\text { \% Physicians } \\
\text { Who Recommended } \\
\text { CAM Use }\end{array}$ & $\begin{array}{l}\text { \% Patients Who } \\
\text { Told Provider } \\
\text { of CAM Use }\end{array}$ & $\begin{array}{c}\text { \% Physicians } \\
\text { Unatuare of } \\
\text { Patient's CAM Use }\end{array}$ \\
\hline $\begin{array}{l}\text { Personal therapies (including home } \\
\text { remedies, herbal medicine, } \\
\text { homeopathy, or vitamin therapy) }\end{array}$ & 425 & $15.2 \%$ & $25.8 \%$ & $62.9 \%$ \\
\hline $\begin{array}{l}\text { Relaxation techniques (including } \\
\text { massage therapy, imagery, } \\
\text { or visualization) }\end{array}$ & 399 & $31.4 \%$ & $18.1 \%$ & $56.2 \%$ \\
\hline Chiropractors & 314 & $24.7 \%$ & $34.1 \%$ & $49.6 \%$ \\
\hline $\begin{array}{l}\text { Healing (including healers, spiritual, } \\
\text { healing, Native American healers, } \\
\text { or energy healing) }\end{array}$ & 73 & $7.4 \%$ & $21.3 \%$ & $72.9 \%$ \\
\hline Commercial weight loss programs & 68 & $16.6 \%$ & $33.2 \%$ & $55.7 \%$ \\
\hline Life-style diets & 65 & $33.2 \%$ & $35.2 \%$ & $43.3 \%$ \\
\hline Self-help groups & 41 & $33.4 \%$ & $42.7 \%$ & $38.2 \%$ \\
\hline Hypnosis or biofeedback & 29 & $39.3 \%$ & $12.1 \%$ & $53.4 \%$ \\
\hline Any CAM use & 801 & $23.7 \%$ & $25.7 \%$ & $56.8 \%$ \\
\hline
\end{tabular}

CAM type, users generally reported positive experiences with these treatments, indicating they would recommend the treatments to family or friends. Judgments of the treatments' effectiveness varied correspondingly: about three quarters of those using healing therapies, life-style diets, and self-help groups reported them extremely or very effective, compared with less than one half of users of commercial weight loss programs.

As noted earlier, searching for consensus in defining CAM and its components may obscure more fluid and dynamic social, cultural, and economic realities. ${ }^{19}$ Although antiscientific, non-Western, religious, and counter-cultural concepts and therapies are likely to rise and fall in public popularity, well-designed trials using the methods of modern medical research increasingly are being undertaken to determine the effectiveness of various treatments currently being classified as CAM..$^{20}$ Therapeutic or preventive approaches and interventions, whether they originate inside mainstream medicine or without, can be found more or less effective by these means. Such evidence may factor into whether a treatment will be widely adopted in alternative provider practice or in self-care, or integrated within mainstream medical practice. Effectiveness is rarely the sole or even predominant determinant of the use and advocacy of particular treatments when healthcare beliefs, practices, values, and interests conflict. This is shown even within mainstream medicine in the well-documented problems of aligning professional practice with evidence of effectiveness. At the same time, the relatively affluent, well-educated health care consumers (those we find most likely to use CAM now) may feel competent to judge and feel empow- ered to demand evidence of effectiveness for preventive or therapeutic interventions. The high level of consumer interest, use, and investment in CAM presage more boundary shifting in the modern medical paradigm and continuing struggles for professional and regulatory control.

Our research suggests that in South Carolina, there is not currently a high level of physician involvement in the use of the defined complementary and alternative treatments, though this varies considerably across treatment types. Overall, physicians are aware of CAM use for about $45 \%$ of their patients who are users. Those treatments with higher physician recommendation rates conceptually appear to be "complementary" rather than truly "alternative." These more complementary therapies may provide a snapshot of the frontline territory in the integration of CAM with mainstream medical care. Associating CAM therapies with medical practice may increase acceptability and use of certain therapies. About one third of our respondents indicated that a physician's recommendation would make them more likely to try a CAM therapy. Future research is needed to determine the impact of the growing use of CAM on public health, medical training, and medical practice in South Carolina and nationally.

\section{References}

1. Eisenberg DM, Davis RB, Ettner SL, et al: Trends in alternative medicine use in the United States: results of a follow-up national survey. JAMA 1998; 280: I549-1640

2. Landmark Healthcare Inc: The Landmark Report on Public Perceptions of Alternative Care. Sacramento, Calif, Landmark Healthcare, 1997

3. Astin JA: Why patients use alternative medicine: results of a national study. JAMA 1998; 279:1548-1553

4. Paramore LC: Use of alternative therapies: estimates from the 1994 Robert Wood Johnson Foundation National 
Access to Health Care Survey. J Pain Symptom Manage 1997; 13:83-89

5. Millar WJ: Use of alternative health care practitioners by Canadians. Can J Public Health 1997; 88:154158

6. MacLennan AH, Wilson DH, Taylor AW, et al: Prevalence and cost of alternative medicine in Australia. Lancet 1996; 347:569-573

7. Kilgore C: Expanding coverage signals growing demand, acceptance for alternative care. Med Health 1998; $52: 3$

8. Pelletier KR, Marie A, Krasner M, et al: Current trends in the integration and reimbursement of complementary and alternative medicine by managed care, insurance carriers, and hospital providers. Am J Health Promot 1997; 12:112-123

9. Wetzel MS, Eisenberg DM, Kaptchuk JJ, et al: Courses involving complementary and alternative medicine at US medical schools. JAMA 1998; 280:784787

10. Eisenberg DM, Kessler R, Foster C, et al: Unconventional medicine in the United States: prevalence, costs, and patterns of use. N Engl J Med 1993; 228:246-252

11. Burg MA, Hatch RL, Neims AJ: Lifetime use of alternative therapy: a study of Florida residents. South Med J 1998; 91:1126-1131
12. Lin JH: Evaluating the alternatives. JAMA 1998; 279:706

13. Jonas $\mathrm{W}$ : Alternative medicine and the conventional practitioner. JAMA 1998; 279:708-709

14. Ernst E: Research at the Department of Complementary Medicine, University of Exeter. Adv Mind Body Med 1998; 14:151-156

15. Panel on Definition and Description, CAM Research Methodology Conference, April 1995: Defining and describing complementary and alternative medicine. Alternative Ther Health Med 1997; 3:49-57

16. Norusis MJ: SPSS/PC+ Advanced Statistics, Version 5.0, Chicago, SPSS Inc, 1992

17. Gart JJ, Thomas DG: The performance of three approximate confidence limit methods for the odds ratio. $A m J$ Epidemiol 1982; 115:453-470

18. Fleiss JL: Statistical Methods for Rates and Proportions. New York, John Wiley \& Sons, 1981

19. Sampson W: Synopsis of the Alternative Medicine Debate. HMS Beagle (e-journal only, issue 49 , posted March 5,1999 ) [www.biomednet.com/hmsbeagle/49/cutedge/synopsis.htm]

20. Cochrane Collaboration: CAM Module. Cochrane Library [CD-ROM] on-going quarterly 